\title{
PERSPEKTIF THE RESOURCE BASED VIEW (RBV) DALAM MEMBANGUN COMPETITIVE ADVANTAGE
}

\author{
Oleh : H. Ating Sukma*
}

\begin{abstract}
Abstrak
Makalah ini bertujuan untuk menganalisis kerangka dari teori Resource Based View ( $R B V)$ yang dikemukakan para ahli dalam pembahasan manajemen strategik dan tertutama yang berkaitan dengan kekuatan dan kelemahan perusahaan dengan cara mengidentifikasi apa yang menjadi kekuatan dan kapabilitas perusahaan serta menghindari kelemahan yang dimiliki untuk keunggulan bersaing, dengan penekanannya pada konsep tentang RBV dan menganalisis perkembangan teori RBV dalam manajemen stratejik,serta menganalisis lingkungan internal dilihat dari sudut kekuatan dan kelemahan yang akan membantu perusahaan agar mampu mengambil keuntungan dari peluang-peluang yang ada dan mampu menghindari dinamis ancaman yang mungkin timbul.Metode penelitian yang digunakan adalah berdasarkan pendekatan historis dan review literatur dari pendapat para ahli yang membahas teori $R B V$ dalam kaitannya dengan kapabilitas dan kompetensi dalam menciptakan daya saing yang unggul,

Studi ini akan memberikan gambaran mengenai karateristik dari pendekatan sumber daya yang dapat memberikan kontribusi dalam praktek manajemen strategi dan meningkatkan kapabilitas serta kompentensi dari perusahaan untuk meningkatkan keunggulan bersaing melalui pendayagunaan sumber daya, baik yang bersifat fisik maupun non fisik. Dengan memperhatikan kekuatan dan kelemahan,diharapkan perusahaan dapat mengoptimalkan core competencies sumber daya yang dimilikinya dan dapat meningkatkan keunggulan bersaing perusahaan.

Pada makalah ini akan diarahkan kepada analisa berbagai pendapat para ahli ekonomi mengenai kerangka sumber daya yang akan menghasilkan suatu kapabilitas yakni keahlian-keahlian yang ada pada setiap individu,serta menganalisa keunikan dari sumber daya yang dimiliki baik yang bersifat fisik, maupun yang bersifat intangible assetsyang akan mendukung keunggulan bersaing dari suatu perusahaan
\end{abstract}

Keywords :Resource Based View,Kapabilitas,Kompetensi,Keunggulan Bersaing

\section{A. PENDAHULUAN}

Dalam beberapa dekade terahir ini muncul perbincangan yang menarik berkaitan dengan teori RBV. Pendekatan dari tinjauan sumber daya ini merupakan suatu kerangka ilmu yang mendorong diskusi diantara para akademisi.

Pendekatan ekonomi klasik ini menarik perhatian sejumlah peneliti sehingga menimbulkan adanya dialog dari berbagai perspektif. The RBV ini merupakan ilmu manajemen yang baik, karena mendorong adanya perbincangan dalam bidang manajemen strategi, seperti yang dikemukaan Mc Clockey (1985) yakni: 'good science is good conversation'.

Studi dari keunggulan bersaing merupakan salah satu dari pembahasan dari RBV, berdasarkan studi dari J. Mahoney dan J. Rajendran (1992), secara garis besar pembahasan Resource Based Theory ini dapat ditinjau dari tiga perspektif.

Pertama, tinjauan berdasarkan konsep manajemen strategi; yang meliputi keunggulan bersaing sebagai dasar dari $\mathrm{RBV}$, termasuk teori yang berhubungan dengan return dan kinerja di bidang strategi (Ramanujam and Varadajan,1989). 
Kedua pendekatan RBV di dalam organisasi ekonomi yaitu yang berkaitan dengan positive agency theory, property right, transaction cost economic dan evoluationary economic.

Ketiga Pendekatan RBV yang berorientasi kepada analisis organisasi industri. Berkaitan dengan Analisa Lingkungan Internal maka pembahasan makalah ini lebih difokuskan kepada halhal yang berkaitan dengan kekuatan dan kelemahan dari manajemen strategi dalam mempertahankan keunggulan bersaing.

Prinsip RBV berkaitan dengan teori keunggulan bersaing dan untuk memperoleh sustainable competitive advantage mengharuskan perusahaan untuk memperoleh economic rents ataureturn. Karateristik sumber daya yang mempunyai keunggulan dapat diperoleh jika sumber daya tersebut mempunyai nilai yang unik, sulit untuk ditiru dan sulit mendapatkan barang subsitusinya. RBV merupakan pilihan dari strategik yang akan dilakukan untuk mengembangkan dan memaksimalisasi return.

Perkembangan RBV selama beberapa dekade ini telah memberi kontribusi di bidang ekonomi dan manajemen strategis baik yang berusaha untuk memperbaiki konsep RBV atau menggunakannya sebagai kerangka kerja untuk menangani pertanyaan yang konseptual dan empiris. Kontribusi utama dari pandangan berbasis sumber daya perusahaan merupakan teori competitive advantage. Logika dasarnya adalah dimulai dengan asumsi bahwa hasil yang diinginkan dari upaya manajerial dalam perusahaan adalah keuntungan kompetitif yang berkelanjutan. Mencapai keunggulan kompetitif yang berkelanjutan, me-mungkinkan perusahaan untuk memper-oleh 'economic rent' atau di atas rata-rata return.
Berkaitan dengan RBV ini, untuk mempertahankan keunggulan bersaing terletak pada kepemilikan sumber daya kunci tertentu, yaitu sumber daya yang memiliki ciri-ciri seperti nilai, hambatan untuk duplikasi dan appropriability. Keunggulan dapat diperoleh jika perusahaan secara efektif mengoptimalkan sumber daya ini. RBV menekankan pilihan strategis, mengoptimalkan sumber daya manusia, mengelola, mengidentifikasi, mengembangkan dan menggunakan sumber daya utama untuk memaksimal-kan nilai perusahaan. Hingga akhir 1980-an, pandangan berbasis sumber daya ditandai dengan proses yang agak terbatas. Pembahasan terhadap pentingnya potensi perusahaan-sumber daya tertentu dapat ditemukan dalam karya ekonom seperti Chamberlin dan Robinson pada tahun 1930-an (Chamberlin 1933; Robinson 1933) yang kemudian dikembangkan oleh Penrose (1959). Para ekonom ini menyatakan bahwa aset dan kemampuan unik dari perusahaan-perusahaan merupakan faktor penting yang menimbulkan persaingan tidak sempurna dan pencapaian laba normal. Sebagai contoh, Chamberlin dalam Hari (1994) dan Hall (1992), mengidentifikasi bahwa beberapa kunci perusahaan termasuk kemampuan pengetahuan teknis, reputasi, brand awareness, kemampuan manajer untuk bekerja sama dan terutama, paten dan merek dagang, banyak yang telah ditinjau ulang.

Edith Penrose's memunculkan teori pertumbuhan perusahaan (Penrose 1959) yang memberikan argumen dari pandangan berbasis sumber daya dalam literatur ekonomi. Dia mencatat bahwa, suatu perusahaan bukan hanya satu unit administrasi, namun merupakan kumpulan sumber daya produktif. Kutipan di atas 
menyoroti dimensi penting dari pandangan berbasis sumber daya pikiran selama dekade terakhir, yaitu, peran manajer dalam pengembangan dan penyebaran sumberdaya (Amit dan Schoemaker 1993; Barney 1986, Barney dan Zajac 1994, Lei, Hitt dan Bettis 1996; Schoemaker 1992) dan hubungan sumber daya dan lingkup perusahaan (Chatterjee dan Wernerfelt 1991; Markides dan Williamson 1996; Prahalad dan Hamel, 1990; Robins dan Wiersema 1995).

Penrose (1959) juga menyatakan bahwa sumber daya tidak hanya bersifat fisik tapi juga dapat merupakan non fisik. Dengan kata lain, jasa yang dihasilkan oleh sumber daya adalah fungsi dari sumber daya yang digunakan, dalam arti bahwa sumber daya yang sama bila digunakan untuk tujuan yang berbeda atau dengan cara yang berbeda atau dikombinasikan dengan sumber-sumber lain menyediakan layanan yang berbeda. Penrose (1959) melihat perbedaan ini sebagai sumber keunikan setiap individu perusahaan dan merupakan perbedaan yang memiliki banyak kesejajaran dengan pemisahan sumber daya dan kemampuan yang mencirikan sebagian besar literatur stategi (Hill dan Jones 1998). Penrose berpendapat bahwa sumber dayainternal memfasilitasi dan membatasi arah perluasan perusahaan yang berlaku untuk perluasan eksternal seperti meningkatnya permintaan dan perubahan dalam teknologi, dan lain-lain

Dalam pandangan berbasis sumber daya Wernerfelt (1984), Barney (1991), Prahalad dan Hamel (1990), Peteraf (1993) dan Conner (1991) berpendapat bahwa pengetahuan dipandang sebagai aset strategis dengan potensi untuk menjadi sumber keunggulan kompetitif yang berkelanjutan sebuah organisasi. Pandangan berbasis perusahaan (Grant,
1995, 1996) ini dibangun berdasarkan sumber daya dan memperluas teori yang dipromosikan oleh Penrose (1959) dan dikembangkan oleh orang lain (Alavi dan Leidner 2001). Hal ini mencakup aspek efisiensi, fleksibilitas dan dasar dalampengangambilan keputusan .

Berdasarkan pemikiran para ahli ekonomi diatas menggambarkan bahwa teori Resource Based View merupakan ilmu yang menarik untuk diperbincangkan.

\section{Definisiresource Based Value}

Keberhasilan atau kegagalan suatu organisasi sangat tergantung kepada faktor sumber daya. Keunggulan bersaing suatu organisasi merupakan kekuatan perusahaan yang sangat didukung oleh sumber daya yang baik dalam kerangka sistem pengelolaan sumber daya yang bersifat strategic, integrated, saling berhubungan dan unity. Persaingan merupakan inti keberhasilan atau kegagalan perusahaan. Persaingan memerlukan ketepatan aktivitas dari suatu perusahaan seperti inovasi dan budaya kerja yang baik. Berkaitan dengan pendekatan teori Resource Based Value, berikut ini disajikan beberapa pendapat dari para ahli ekonomi khususnya bidang strategic marketing.

Hal penting menurut Mahoney dan Pandian (1992) ketika membahas RBV adalah sangat berkaitan dengan perolehan margin dan kombinasi sumber daya yang tidak mudah untuk ditiru atau digantikan termasuk di dalamnya adalah tangible dan intangible assets. Margin yang diperoleh dapat berasal dari sumber daya yang langka sehingga mempunyai nilai yang tinggi. Dalam menghasilkan keunggulan bersaing yang berkelanjutan menurut Powell (1992) harus mampu memberikan nilai ekonomis yang tinggi yang sulit untuk ditiru atau 
digantikan. Pendapat ini banyak diikuti oleh pemikir-pemikir lainnya, karena jika sumber daya sulit tergantikan maka nilai ekonomis dari sumber daya akan bernilai ekonomis yang tinggi.

Bates dan Flynn (1995) menekankan bahwa sumber daya akan mempengaruhi kinerja perusahaan dan juga menyatakan sesuatu yang langka, sulit ditiru oleh yang lain mendorong timbulnya keunggulan bersaing. Sementara Litz menyatakan bahwa karakteristik sumber daya itu bersifat simultan dari sifat yang berkaitan dengan kelangkaan, sulit ditiru dan tergantikan. Kepemilikan sumber daya menurut Michalitin Smith dan Kine (1997) dapat menentukan apakah organisasi dapat memperolehprofit yang tinggi atau tidak, jadi pengontrolan atas aset yang strategis sangat dibutuhkanBowen \& Wiersema (1999) berpendapat kinerja perusahaan sangat tergantung kemampuan dasar dalam memberikan sumber daya yang unik dan spesifik. Sumber daya dikatakan bernilai menurut Combe and Ketchen (1999) adalah jika pembeli untuk membeli diatas harga pokok dan pesaing sulit untuk meniru produk yang dihasilkan. Organisasi juga harus mampu untuk mengendalikan serangkaian sumber daya yang unik, keanekaragaman sumber daya yang unuk akan memberikan nilai tambah yang bernilai bagi perusahaan (Rindova and Fombrun, 1999). Di dalam menganalisis keunggulan bersaing ada asumsi yang harus dipenuhi yaitu yang berkaitan dengan pengendalian sumber daya yang strategis dan berdaya tahan lama.

Keunikan sumber daya, efisiensi yang dapat memberikan margin optimal, menurut Penrose dalam Rugman and Verbeke (1998) merupakan daya dukung yang kuat untuk menghadapi pesaing. Halawi, Aronson, dan Richard (2005),
Prahalad and Hamel (1990); Conner and Prahalad (1990) dan Priem (2001),memasukan unsur knowledge sebagai salah satu faktor yang harus dipertimbangkan dalam menilai kompetensi, karena knowledge akan memberikan nilai tambah bagi terciptanya keunggulan bersaing. Fonss, Knudsen dan Montgomery dalam Rugman dan Verbeke (1995) kembali menyatakan bahwa keunikan akan membuat pesaingsulit untuk menirunya. Namun demikian sumber daya juga dipengaruhi oleh proses dan bagaimana menggunakannya, sehingga dapat diperoleh hasil yang optimal.

Dari berbagai pendapat para ahli, maka pembicaran teori RBV merupakan kekayaan milik perusahaan baik yang bersifat fisik maupun non fisik, dimana untuk dapat mencapai keunggulan bersaing yang berkelanjutan maka sumber daya haruslah mempunyai nilai tambah ekonomis, yang mempunyai karateristik sulit untuk ditiru dan tidak mudah untuk digantikan.

\section{Teori dan Model RBV}

Teori RBV merupakan teori yang banyak diperbincangkan dan sering dijadikan acuan dalam membahas analisis lingkungan internal organisasi. Teori ini seringkali diperdebatkan oleh para ahli yang berkaitan dengan model RBV. Berikut ini disampaikan beberapa contoh model yang diajukan oleh para ahli strategic management.

\section{a. RBV Kaitannya dengan Konsep Manajemen Strategi.}

Meliputi keunggulan bersaing sebagai dasar dari RBV, termasuk teori yang berhubungan dengan return dan kinerja di bidang strategi (Resource Based Theory Within The Conversation of Strategy). Pada 
pendekatan ini strategi memfokuskan padaperolehan rent yaitu merupakan pendapatan atas kelebihan dari opportunity cost atas sumber daya pemilik. Rents dapat diperoleh dengan memiliki sumber daya bernilai yang langka (Ricardo, 1817). Sumber daya ini menghasilkan apa yang disebut Ricardian rents termasuk kepemilikan dari tanah yang berharga, keunggulan lokasi, paten dan copyright.

Monopoly rent dapat diperoleh dengan proteksi pemerintah atau dengan collusive arrangements dimana adanya hambatan dari persaingan potensial yang tinggi (Bain, 1968). Entrepreneurialrent dapat diperoleh dengan pengambilan risiko dan kemampuan entreupreneur dalam lingkungan yang compleks/penuh ketidakpastian (Cooper, Gimeno-Gasconand Woo (1991), Rumelt (1987), Schumpeter (1934).

Pandangan berdasarkan sumber daya berkembang dalam manajemen strategi untuk menjelaskan bagaimana perusahaan memperoleh rents. Perusahaan memilih strategi untuk memperoleh rents tergantung kepada kapabilitas sumber daya mereka. Organisasi dengan kapabilitas untuk mengevaluasi secara efektif posisi sumber daya dalam hal kekuatan dan kelemahan mampunyai dasar yang kuat untuk keunggulan bersaing (Andrews, 1971). Teory rents membawa kita untuk menguraikan kerangka SWOT dengan mengidentifikasi benar-benar apa yang menjadi kekuatan dan kapabilitas perusahaan untuk keunggulan strategik. Perusahaan yang mempunyai keunikan kapabilitas dalam kemampuan teknis dan manajerial merupakan sumber daya yang penting untuk dapat mempertahankan keunggulan bersaing. Secara khusus, keunggulan yang berbeda/unik dan kegiatan rutin organisasi yang unggul dalam satu atau lebih rantai nilai memungkinkan perusahaan mendapakan rents dari kenggulan bersaing (Hitt and Ireland, 1985). Sebagai contoh top magement dari suatu perusahaan jika mempunyai sumber daya yang memadai dan sumber daya yang berbeda/unik akan memberikan kontribusi perolehan keuntungan perusahaan (Castanias and Helfat, 1991).

Perusahaan memperoleh rents bukan karena mempunyai sumber daya yang lebih baik, tetapi lebih disebabkan kompetensi yang unggul dalam penggunaan sumber daya (Penrose, 1959;54). Pemikiran ini menyatakan bahwa sumber daya perusahaan saat ini dipengaruhi oleh persepsi manajerial dan karenanya arah dari pertumbuhan adalah preposisi kognitif yang menguatkan alasan ekonomi bahwa sumber daya akan dipengaruhi oleh diversifikasi (Wernerfelt, 1984).

Tinjauan dari aspek sumber daya berkontribusi besar terhadap aliran dari penelitian strategi diversifikasi (Ramanujam dan Varadamjan, 1989) dalam tiga bidang :

\section{1) Pendekatan $R B V$ mempertimbangkan keterbatasan dari pertumbuhan diversifikasi (melalui pertumbuhan internal dan merger serta akuisisi) \\ Pada dasarnya ada keterbatasan} sumber daya dari perusahaan berkaitan dengan pasar yang akan dimasuki dan keuntungan yang diharapkan (Wernerfelt, 1989). Keterbatasan sumber daya ini meliputi kekurangan tenaga kerja dan input fisik, keuangan, kesempatan investasi yang tepat dan langkanya kapasitas manajemen yang suffisien.

Dalam Theory Penrose'manajemen merupakan akselerator dan pengendali untuk proses pertumbuhan (Starbuck, 1965:490). Kendala manajerial dalam 
pertumbuhan perusahaan disebut 'Penrose Effect' (Marris 1963), artinya bahwa pertumbuhan perusahaan yang cepat pada suatu periode cenderung mengakibatkan pertumbuhan yang lambat pada periode berikutnya. Kesimpulan dari Penrose Effect adalah adanya ketergantungan yang tinggi akan sumber daya menyebabkan rendahnya tingkat pertumbuhan perusahaan (Robinson, 1932).

\section{2) Pendekatan $R B V$ mempertimbangkan} pentingnya motivasi dalam diversifikasi

Sebagai tambahan dalam menganalisis keterbatasan dalam tingkat pertumbuhan, Penrose $(1955,1959)$ juga menganalisis motif untuk ekspansi, sangat jarang dalam sebuah organisasi yang seluruh unitnya beroperasi dalam kecepatan dan kapasitas yang sama, dan fenomena ini menciptakan rangsangan internal untuk pertumbuhan perusahaan.

Penrose (1985:13) memberikan pernyataan pendekatan sumber daya meyatakan bahwa perusahaan adalah organisasi administrasi dan sekumpulan aset fisik,human dan intangible assets. Kapabilitas perusahaan mempengaruhi produk akhir yang meliputi skill, kapasitas dan sumber daya yang dinamis yang akan memberikan bermacam-macam produk akhir (Caves 1984, Teece, 1982, Ulrich and Lake, 1990). Kelebihan kapasitas fisik membawa diversifikasi jika produk akhir spesifik (Chstterjee and Wernerfelt, 1988).

3) Pendekatan $R B V$ menyediakan sebuah teori rasional untuk memprediksi kinerja yang tinggi untuk kategori tertentu yang berhubungan dengan diversifikasi

Rubin (1973) membuat model keputusan diversifikasi perusahaan berdasarkan Penrose's theory. Model program dinamik Rubin (1973) mengilustrasikan makalah Penrose's bahwa ada pertumbuhan yang optimal dalam perusahaan. Pertumbuhan yang optimal dalam perusahaan meliputi keseimbangan antara eksploitasi dari sumber daya yang ada dan pengembangan dari sumber daya yang baru (Penrose, 1959, Rubin, 1973, Werner-felt, 1984).

Beberapa studi ekonometrika mendukung teori RBV bahwa sumber daya perusahaan yang spesifik membawa kekuatan dalam strategi diversifikasi. Lemelin (1982) menyatakan bahwa pola ini konsisten dengan hipotesis RBV bahwa perusahaan berusaha untuk mentransfer intangible assets di dalam kegiatan yang berkaitan. Sama halnya dengan Steward, Harris and Carleton (1984) menemukan hubungan positif yang sangat kuat antara intensitas publikasi perusahaan dengan publikasi industri. Pengeluaran untuk publikasi merupakan alasan yang efektif untuk memperkuat intangible assets (seperti brand namedan reputasi). Montgomery and Harihanan (1991) memberikan dukungan lanjutan terhadap RBV teori yang menyatakan bahwa profil sumber daya dapat memprediksi karakteristik sumber daya dari industri yang dituju.

Berdasarkan penelitian terdahulu tentang kaitan perusahaan dengan industri dan hubungan antara industri yang utama dengan industri yang dituju. Montgomery dan Hariharan (1991) memberikan kontribusi yang signifikan dengan menggunakan data bisnis untuk menggambarkan profil dari berbagai perusahaan.

Diversikasi teori dari sumber daya menyatakan bahwa dampak terhadap perusahaan mungkin ada dalam bentuk fokus aktivitas perusahaan, alasannya; 
a) Diversifikasi yang luas membuat perusahaan kurang fokus, sehingga dapat mengurangi rents.

b) Sumber daya yang ada akan berkurang nilainya ketika ditransfer ke pasar yang tidak mirip dengan aslinya.

\section{b. RBV Kaitannya dengan Organizational Economics}

Pada pendekatan ini RBV dilihat dalam konteks yang dinamis berkembang mulai dari teori neo klasik yang mengasumsikan tidak ada transsaction cost,ketidakpastian teknologi, sampai kepada paradigma ekonomi yang meliputi economics evolutionary. Sumber daya unggulan pada tahap perkembangan ekonomi dinilai berbeda, tergantung pada tahapan yang dilaluinya, dimana dalam perjalanannya mulai dari era pertanian, era industri, era jasa dan kemudian tahun 1990an menuju era informasi. Perubahan pada tahun 1990-an dengan masuknya era digitalisasi banyak mengubah pandangan terhadap sumber daya.

The Resorce Based Value dari keunggulan kompetitif juga dapat dianalisis dalam konteks evolutionary. Keunggulan kompetensi perusahaan dapat didefinisikan sebagai sekumpulan peraturan yang rutin digunakan oleh top manajemen. Keputusan manajemen di masa lalu dan peraturan dalam pengambilan keputusan merupakan hal dasar yang akan mempengaruhi perusahaan. Pendekatan RBV juga diselaraskan dengan teori lain di dalam paradigma organisasi ekonomi (Barney and Ouchi, 1986). The RBV berhubungan dengan property rights semenjak property rights digambarkansebagai sumber daya yang bernilai, property rights menjadi lebih presisi (Libecap, 1989). Pada akhirnya teori
RBV berhubungan dengan teori transaction costa karena kombinasi sumber daya akan dipengaruhi oleh transaction costs.

Pada dasarnya paradigma organizational economics, yang terkait dengan transaction cost theory, positive agency theory dan property rights theoryadalah dalam upaya untuk menjelaskan asal, fungsi, evolusi dan sustainability dari suatu institusisumber daya yang bernilai sulit untuk ditiru dan disubsitusi serta memungkinkan perusahaan memperoleh dan mempertahankan rents.

\section{c. RBV Kaitannya dengan Organizational Industrial}

Poteraf (1990) memberikan kontribusi kepada teori RBV dengan secara sistimatik membandingkan kerangka klasik Porter dari Havard School dan RBV dari perusahaan. Peteraf (1990) juga membandingkan 'Chicago School (Stigler, 1968) tinjauan dari industrial organizational dengan RBV. Konsep teori yang esensial untuk menjelaskan sustainability dari rents dan kerangka RBV adalah isolating mechanism (Rumelt, 1984) yang merupakan analogi dalam menghadapi kendala dalam level industri dan mobilitas kendala dalam level grup strategis (Caves and Porter, 1977; Mc Gee and Thomas, 1986). Dalam hal ini RBV merunakan konsep sentral dari paradigma kinerja stuktur strategi dalam berbagai level analisis. Pendekatan isolation mechanism menjelaskan aliran yang stabil dan menyediakan hal yang rasional dalam menghadapi perbedaan didalamindustri diantara perusahaan-perusahaan.

Isolating mechanism mengindikasikan adanya campur tangan pemerintah, dan keberadaanya karena asset specificity dan bounded rationality (Williamson,1979). 
Atau isolating mechanism merupakan hasil dari hubungan yang erat antara uniqueness dan causal ambiguity (Lippman and Rumelt, 1982). Alasan yang komprehensif mengenai strategi, organizational economics dan organizational industry dapat diungkapkan oleh artikel-artikel yang terus berkembang. Pendekatan RBV muncul untuk membangkitan pemikiran pemikiran intelectual yang baru (Conner, 1991).

Model RBV dalam ilmu manajemen strategi terus dikembangkan dari tahun ke tahun, dan beberapa model dikemukakan sebagai berikut :

\section{Model Mahoney and Pandian}

a. Integrasi dari munculnya RBV dengan organizational economics dapat memberikan nilai tambah dalam implementasi dari strategi diversifikasi (Chatterjee, 1990; Lamont and Anderson, 1985; Simmonds, 1990; Yip, 1982).

b. Premis dasar yang membedakan industrial organization dari strategic management merupakan asumsi dari heterogeneous perusahaan. Srategi memberikan dasar teori yang cukup kuat. Keuntungan dari strategi ini adalah pengembangan model dimana heterogenity perusahaan adalah kreasi endogenous dari pelaku ekonomi.

c. Integrasi dari RBV dengan strategic group, dimana dalam kenyataannya seperti yang dikatakan Mc Gee and Thomas 'strategic group analysis has interesting parallels with the theory of growth of the firm as first articulated by Downie, Penrose and Marris more than 20 years ago (1986:157). Sumberdaya yang tak dapat ditiru dapat menjadi sumber dalam mempertahankan keunggulan strategic group.

d. Integrasi RBV dengan industri merupakan alternatif untuk mencapai keunggulan bersaing. Keunggulan bersaing adalah fungsi dari analisis industri, organizational governance dan firm effects (dalam bentuk keunggulan sumber daya dan strategies). The RBV model dinilai potensial untuk menyatukan penelitian-penelitian untuk memperkaya dan meneguhkan teori strategi perusahaan (Conner, 1991; Rumelt, 1984).

\section{b. Model Barney}

a. Model ini menggambarkan bagaimana sumber daya berhubungan dengan strategi perusahaan, dimana perusahaan harus memperhatikan nilai sumber daya, kelangkaan, sulit ditiru dan mampu mengeksplorasinya lebih mendalam.

b. Dalam implementasinya ada dua pendekatan yaitu kemampuan dalam menerapkan strategi akan memberi dampak positif dalam pengoptimalan sumber daya, dan dalam implementasinya sumber daya potensial ini perlu pengendalian. 


\section{c. Model Rugman and Verbeke}

\begin{tabular}{|c|c|c|}
\hline $\begin{array}{l}\text { Key managerialgoal } \\
\text { Key conditions } \\
\text { for goal achievement }\end{array}$ & Rent & Optimal growth pattern \\
\hline $\begin{array}{l}\text { Isolating mechanisms and resource } \\
\text { superiority vish-a-vish rivals }\end{array}$ & $\begin{array}{l}\text { Modern resource based } \\
\text { approach }\end{array}$ & $\begin{array}{l}\text { Economics driven } \\
\text { international business } \\
\text { theory }\end{array}$ \\
\hline $\begin{array}{l}\text { Balanced sequence of resource } \\
\text { development/use } \\
\text { asequisition/absorption }\end{array}$ & $\begin{array}{l}\text { Dynamic capability } \\
\text { approach }\end{array}$ & Penrosian approach \\
\hline
\end{tabular}

Kondisi kunci untuk mencapai tujuan dipengaruhi oleh isolating mechanism dan balanced sequence of resources, sementara kunci keberhasilan manajerial akan dipengaruhi oleh rent dan optimal growth pattern.

\section{d. Model Combs Ketchen}

Cost of Interfirm cooperation

\begin{tabular}{|c|c|c|c|}
\hline & & High & Low \\
\hline \multirow{2}{*}{ Resourve Level } & High & $\begin{array}{l}\text { Productivity toward } \\
\text { Full ownership }\end{array}$ & $\begin{array}{l}\text { Productivity toward } \\
\text { Interfirm cooperation }\end{array}$ \\
\hline & Low & $\begin{array}{l}\text { Productivity toward } \\
\text { Interfirm cooperation }\end{array}$ & $\begin{array}{l}\text { Productivity toward } \\
\text { Interfirm cooperation }\end{array}$ \\
\hline
\end{tabular}

Gambar 1. Model Combs Ketchen

Model ini mengggambarkan kecenderungan perusahaaan untuk berperan besar terhadap peningkatan kemampuan sumber daya dengan memfokuskan pada meminimumkan biaya organisasi.

\section{e. Model Kathleen and Conner}

\section{Comparison of Resource and Opportunism Based Approach}

\section{a. Convergence}

Objective;Increase Earnings

Through Greater Productivity

\section{Basic Condition : Bounded Rationality}

c. Divergence

d. Some Diverge, Some onvergence

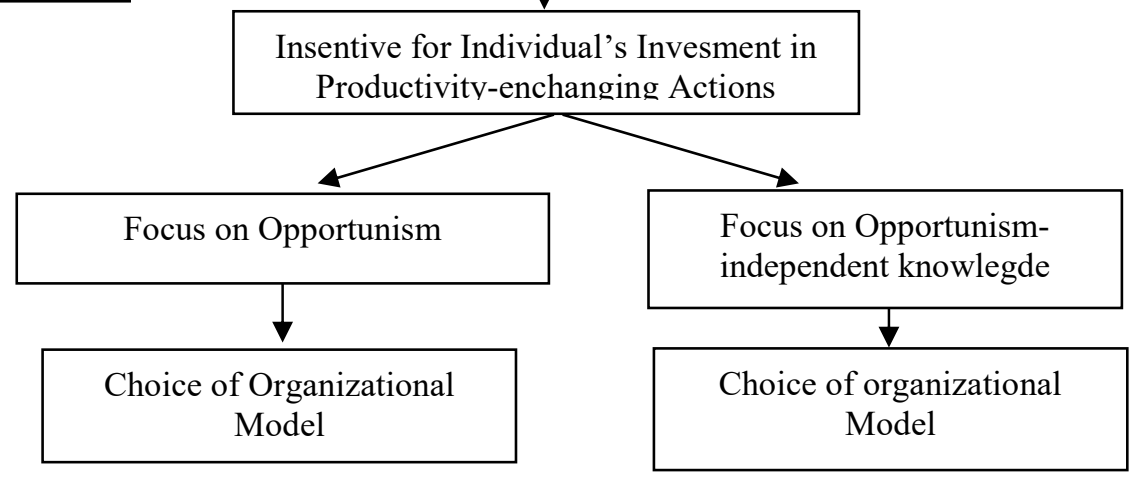

(a) Opportunism-based Approach

(b) Resource based Approach

Gambar 2. Model Kathleen and Conner 
Model Hall (Intangible Resources,Capability Differentials And Sustainable Competitive Advantage)

TYPE OF RESOURCE

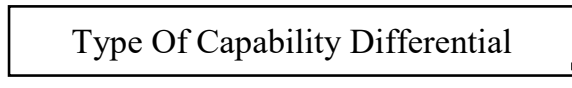

\section{ASSETS}

ASSET WITHIN A LEGAL CONTEXT

- Contracts

- Licences

- Intelectual Property

- Trade Secrets

- Owned Physical Resources

ASSET WITHOUT A LEGAL CONTEXT

- Reputation

- Networks

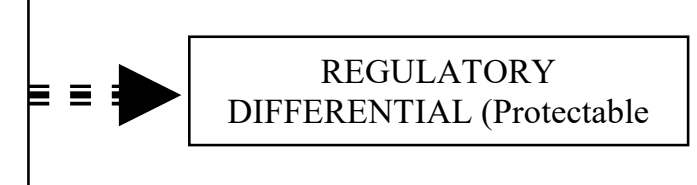

\section{COMPETENCIES}

KNOW-HOW

- Employee Know-how

- Supplier Know-how

- Distributor Know-how,etc

ORGANISATIONAL CULTURE

- Perception of Quality

- Ability to Manage Change

- Perception of Service,etc

\section{POSITIONAL}

DIFFERENTIAL(Due to

Previous Endeavour)

f. Model Fahy\&Smithee (A Resource Based Model of Sustainable Competitive Advantage)

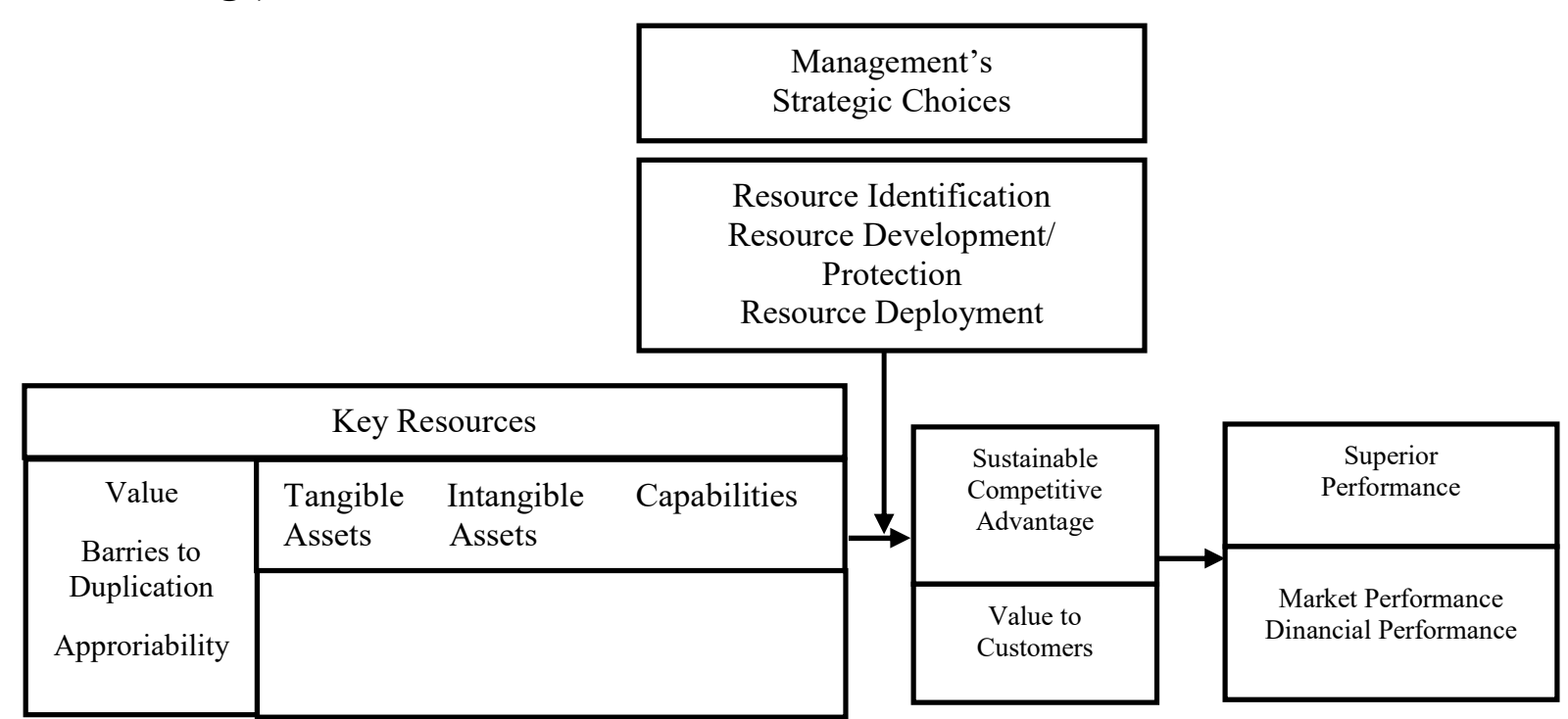

Gambar 3. Model Fahy \& Smithee 


\section{B. Analisis Model}

Prahalad and Hamel menemukan bahwa perusahaan yang sukses adalah perusahaanyang berfokus pada peningkatan kompetensi, yang digunakan dengan cara-cara baru dan inovatif untukmencapai tujuan. Perhatian utama perusahaan adalah menggunakan sumberdayanya dalam cara-cara yang menantang dan kreatif untuk membangun kompetensi inti.

Kompetensi memiliki pengaruh yang kuat terhadap kinerja perusahaan (Absah, 2007). Perusahaan yang memiliki tim manajemen dengan keahlian optimal dan metode bersaing yang didasarkan pada kompetensi inti akan mampu mencapai kinerja yang lebih tinggi dibandingkan perusahaan lain yang tidak dapat melakukannya. Dengan kompetensi superior akan memungkinkan perusahaan memperoleh informa siapa yang dibutuhkan dan diinginkan oleh pelanggannya.

Perusahaan yang memiliki karyawan dengan kompetensi yang tinggi, akan lebih mampu menyediakan produk dan layanan yang sesuai dengan kebutuhan dan keinginan pelanggan. Oleh karena itu, perusahaan dengan kompetensi superior dapat memperoleh keunggulan bersaing yang berkesinambungan dan selanjutnya dapat meningkatkan kinerjanya. Agar dapat mempertahankan keunggulan bersaing tersebut, kompetensi yang dimiliki perusahaan haruslah mampu menambah nilai, langka, sulit ditiru, dan sulit digantikan. Menurut Godfrey and Hill (1995), kompetensi yang tidak mudah ditiru merupakan inti dariteori resource-based, dan sentral pemahaman mengenai keunggulan bersaing yang berkelanjutan.

Kompetensi yang sulit ditiru memiliki hubungan yang positif dengan kinerja dan dilindungi dari peniruan dengan berbagai cara. Kompetensi yang berasal darifaktor seperti lokasi yang strategis, kepemilikan hak cipta, akan melindungi sumberdaya bernilai dari tindakan peniruan oleh pesaing. Sumberdaya yang bersifat socially complex, seperti reputasi yang baik dan kepercayaan merupakan sumberdaya yang membutuhkan waktu dan biaya yang tinggi untuk ditiru.

Resources juga merupakan ambiguitas mengenai hubungan antara kompetensi perusahaan dengan keunggulan bersaing (Reed and De Fillipi, 1990; Barney, 1991) dan akan melindungi kompetensi dari usaha peniruan (Lippmanand Rumelt, 1982; Dierickx and Cool, 1989; Barney, 1991). Causal ambiguity akan melindungi kompetensi dari usaha peniruan karena pesaing tidak mengerti hubungan antara kompetensi ini dengan keunggulan bersaing.

Dalam perjalanannya teori RBV berkembang, dan salah satunya adalah masuknya Knowledge Management sebagai salah satu variabel dari RBV. Knowledge Management adalah sebuah strategi untuk mendapatkan pengetahuan yang benar kepada orang yang tepat pada saat yang tepat dan membantu orang-orang berbagi dan menaruh informasi ke dalam tindakan dengan cara-cara yang akan meningkatkan kinerja organisasi. Knowledge Management dapat dianggap sebagai proses desain yang disengaja, peralatan, struktur, dengan maksud untuk meningkatkan, memperbarui, berbagi atau meningkatkan penggunaan pengetahuan terwakili dalam salah satu dari tiga unsur (struktural, manusia, dan sosial) dari modal intelektual (Seemann, DeLong, Stucky dan Guthrie, 1999).

Knowledge Management mendorong individu untuk mengkomunikasikan pengetahuan mereka dengan menciptakan 
lingkungan dan sistem untuk me pengorganisasian, dan berbagi pengetahuan di seluruh perusahaan (Martinez, 1998: 89). Knowledge Management memiliki dua tujuan utama: (1) untuk membuat organisasi bertindak secerdas mungkin untuk mengamankan kelangsungan hidup dan keberhasilan secara keseluruhan, dan (2) untuk menyadari nilai terbaik dari aset pengetahuan (Wiig, 1997). Tujuan pengetahuan manajemen, dengan demikian, adalah untuk meningkatkan sebuah aset intelektual organisasi dalam mempertahankan keunggulan kompetitif.

Berdasarkan uraian tersebut diatas maka didalam penyusunan model yang berkaitan dengan RBV, haruslah memperhatikan;

1. Konsep dasar yang menyatakan bahwa kunci dari keberhasilan sumber daya terletak pada keungulan bersaing

2. Nilai hubungan timbal balik kompleks antara sumber daya manusia perusahaan dan sumber-sumber daya lain nya: fisik, finansial, hukum, dan faktor lainnya

3. Nilai kompetitifuntuk meningkatkan kemampuan strategisnya

4. Keuntungan dari pengoptimalan human capital.

5. Keunggulan sumber daya manusia memberi kontribusi yang tinggi atas keunggulanbersaing.

6. Dalam analisis lingkungan internal,faktor fungsi bisnis akan sangat mempengaruhi

7. Membuat sesuatu yang unik dan tidak mudah ditiru agar dapatmemperkuat keunggulan bersaing

8. Human resources harus diperkuat bargainning powernya dengan ikutserta nya dalam kepemilikan perusahaan agarloyalitas dan kompentensinya meningkat yang pada gilirannya akan dapat meningkatkan keunggulan bersaing.

9. Memasukan variabel knowlegde management dan business ethic sebagi tambahan atas kriteria dalammencapai Sustainable Advantages.

\section{Penutup}

Penggunaan sumberdaya memiliki banyak keunggulan potensial bagi perusahaan seperti pencapaian efisiensi yang lebih besar dan selanjutnya biaya yang lebih rendah, peningkatan kualitas dan kemungkinan pangsa pasar serta profitabilitas yang lebih besar (Collis, 1994). Pendekatan analitis yang disebut RBV menekankan peningkatan keunggulan bersaing yang berasal dari sumberdaya strategis organisasi, dan dengan keunggulan bersaing memungkin-kan perusahaan memperoleh kinerja unggul.

Inti dari RBV adalah bahwa perusahaan berbeda secara fundamental karena memiliki seperangkat sumberdaya yang berbeda. Pencapaian keunggulan bersaing yang paling efektif adalah dengan menggunakan kompetensi perusahaan.

Pendekatan resource-based menekankan pentingnya sumberdaya internal untuk mencapai keunggulan bersaing yang berkelanjutan. Perspektif ini menyatakan bahwa kinerja perusahaan adalah fungsi dari seberapa baik manajer membangun organisasinya dalam menangani sumberdaya yang bernilai, langka, sulit ditiru dan sulit digantikan (gambar 4).

Perusahaan dengan kompetensi yang bernilai dan langka akan menghasilkan keunggulan bersaing yang lebih besar dibandingkan pesaingnya, yang selanjutnya menghasilkan kinerja keuangan superior. Keunggulan bersaing dan kinerja yang dihasilkan perusahaan merupakan 
konsekuensi dari sumberdaya khusus dan kompetensi yang dimiliki.

Dengan demikian dapat dikatakan bahwa perusahaan harus memiliki kemampuan untuk mengkordinasikan sumberdaya strategis dengan baik, sebab merupakan kunci dalam membangun kompetensi dan pada akhirnya pencapaian kinerja yang tinggi. Namun demikian perlu kiranya untuk melengkapi teori RBV ini dengan perkembangan ilmu masa kini, misalnya memperkaya dengan pendekatan knowledge management, menerapkan etika bisnis, dan unsur yang dapat memperkuat kompentensi inti. Unsur employee shareholder equity (keikutsertaan karyawan dalam kepemilikan perusahaan) dapat dipertimbangkan sebagai motivator untuk lebih meningkatkan loyalitas dan kompetensi sumber daya manusia yang akan berkaitan langsung dengan pencapaian keunggulan bersaing. Pengertian sumber daya ditinjau berbagai perspektif membuka peluang yang besar untuk penelitian selanjutnya dalam rangka mengidentifikasikan variable-variable lain dalam rangka mendukung pencapaian keunggulan bersaing.

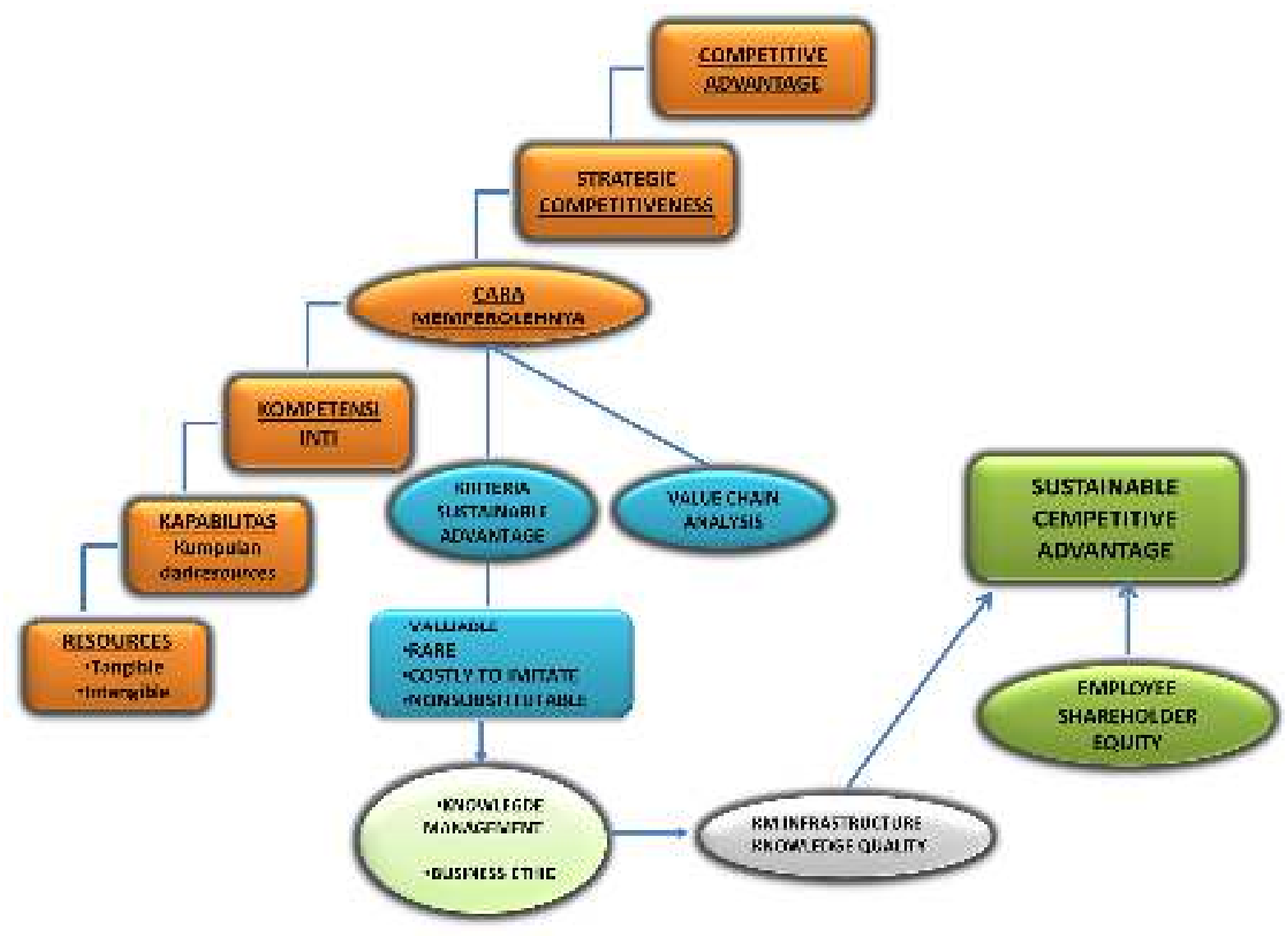

Gambar 4. Peran Resource dalam Mencapai Keunggulan Bersaing 


\section{Daftar Pustaka}

Barney, Jay B The Ohio State University, 2001. Is The Resource Based-View A Usefull Perspective for Strategic Management Research?Yes, Journal Academy of Management Review, Vol. 28, hal 43-45.

Combs, James G., 1999, Explaining Interfirm Cooperation and Performance Toward A Reconcikiation of Prediction From The Resource Based View and Organization Economics, Strategic Management Journal, Vol, 20,hal 868-871.

Conner, Kathleen R, C.K. Prahalad,1996, A Resource-Based Theory of The Firm: Knowledge Versus Opportunism, Journal Organization Science, Vol. 7, No 5 September-Oktober,hal. 490491.

De Galunic, Charles and Simon Rodan, 1998, Resource Recombinations in The Firm: KnowlegdeStructures and The Potential For Schumpeterian Innovation, Strategic Management Journal, Vol 19, hal. 1194-1196.

Fahy, John, 1999, Strategic Marketing and The Resource Based View of The Firm, Journal Academy of Marketing Science Review, Vol. 10, hal. 6-8.

Foss, Nicolai J. 2005, "Scientific Progress In Strategic Management; The Case of The Resource-Based View", The Journal of Learning and Intellectual Capital, nov, hal 5-6

Halawi, Leila, Jay E. Aronson, Richard V. Mc Carthy, 2005, Resource Based View of Knowleledge Management, The Electric Journal of Knowledge Management, Vol. 3 iss. 2, hal. 76.
Hall, Richard, 1992, The Strategic Analysis Of Intangible Resources, Stategic Management Journal, Vol.13, hal. 135-138.

Hall, Richard, 1993, A Framework Linking Intangible Resources And Capabilities To Sustainable Competitive Advantage, Strategic Management Journal, Vol. 14, hal. 610-612

Keeley, Robert and Juan B Roupe, 1990, Management Strategy and Industry Structure As Influences on The Success of New Firm: A Structural Model, Journal Management Science, Vol. 36, iss 10,h al. 1257.

Kraatz, Matthew S and Edward J. Zajac, 2001, How Organizational Resources Affect Strategic Change and Performance in Turbulent Enviroment; Theory and Evidence, Organization Science, Vol. 12 no 5, September-Oktober 2001, pp 634636.

Mahoney, Joseph and T. J. Rajendran Pandian, 1992, The Resource Based View Within The Conversation of Strategic Management, Strategic Management Journal,Vol. 13.

Oliver, Christine, 1997, Sustainable Competitive Advantage : Combining Institutional Resource Based Value, Strategic Management Journal, Vol 18 , iss 9 hal 701 .

Priem, Richard L, 2001, Is The Resource Based Value A Useful Perspective For Strategic Management Reasearch, Academy of Management Review, Vol 25 no 1, hal. 24-29.

Rugman, Alanand Kelley Verbeke, 2002, Edith Penrose's Contribution to the Resources Based View of Strategic 
Management, Strategic Management Journal, j. 23; 771-114.

Stabel, B. Charles,1998, Configurity Value for Competitive Advantage:on Chains, Shopsand Network, Strategic Management Journal, No.19 iss 5, hal. 416.

Williamson,Oliver, 1999, Governance Competencies Perspective, Strategic Management Journal, Vol. 20,hal. 1088.

Wenerfelt, Birger Sloan, 1995, The Resource Based View of The Firm; Ten Years After, Strategic Management Journal, Vol. 16, 171174.

* Dosen Program Studi Ekonomi Islam Universitas Djuanda Bogor 